\title{
Changes in the breeding bird communities on mires and in surrounding forests in southeastern Norway during a 40-year period (1976-2015)
}

\author{
Svein Dale ${ }^{1 *} \&$ Geir Hardeng ${ }^{2}$
}

\author{
${ }^{1}$ Department of Ecology and Natural Resource Management, Norwegian University of Life Sciences, P.O.Box 5003, NO-1432 \\ Ås, Norway \\ ${ }^{2}$ Fuglevik platå 19, NO-1673 Kråkerøy, Norway \\ *Correspondence: svein.dale@nmbu.no
}

\begin{abstract}
The breeding bird communities of 18 mires and surrounding forests in southeastern Norway were censused in 1976-77 and in 2015. We found that 53\% of the mire species with sufficient data for analyses showed significant changes. Red-throated Diver Gavia stellata, Common Crane Grus grus, Wood Sandpiper Tringa glareola and Tree Pipit Anthus trivialis increased, whereas Northern Lapwing Vanellus vanellus, Black-headed Gull Chroicocephalus ridibundus, Meadow Pipit Anthus pratensis and Yellow Wagtail Motacilla flava decreased. There were also near significant decreases of Eurasian Curlew Numenius arquata and Eurasian Skylark Alauda arvensis. Population changes did not differ between short- and long-distance migrants. Species with marginal populations on mires declined more than mire specialist species, suggesting an indirect negative influence of problems in other habitats. Overall, there was a significant $19 \%$ decline in number of mire species, but a non-significant $7 \%$ increase in number of individuals. The bird community in the forests surrounding the mires showed significant population changes for $42 \%$ of the species with sufficient data for analyses, with increases in many resident forest species, but less so for migrants. Overall, there was a near significant $12 \%$ increase in number of forest species, and a significant $28 \%$ increase in number of individuals. Mire- and forest-associated species did not differ in population trends. Among short-distance migrants (mire and forest species combined), species wintering in agricultural habitats had more negative population changes than species wintering in other habitats. Thus, the breeding bird community on and around mires in this part of Norway has undergone large changes during the last 40 years. We discuss our results in relation to general trends of bird communities in northern Europe.
\end{abstract}

Key words: migrants; bog; population changes; residents; wintering habitat

\section{INTRODUCTION}

A large proportion of bird species in Europe are experiencing population declines due to human activities and environmental change. Long-distance migrants, northern boreal species and species breeding in agricultural areas are often regarded as being hit more than other species (Fuller et al. 1995, Donald et al. 2001, Sanderson et al. 2006, Laaksonen \& Lehikoinen 2013, Vickery et al. 2014), but recent studies have also documented large declines among common species in general (Inger et al. 2015). Knowledge of population trends of individual species and for bird communities in specific habitats is important for management and conservation of biodiversity. Studies of bird population changes in Norway have so far focused in particular on seabirds (Fauchald et al. 2015), montane habitats (Byrkjedal \& Kålås 2012, Lehikoinen et al. 2014), or general surveys of mainly terrestrial species (Husby
\& Stueflotten 2009, Kålås et al. 2014). However, population changes of birds in some other habitats have not been studied well, and here we focus on the bird community of lowland mires (bogs) in southeastern Norway for which there have been no comprehensive studies. Mires in southern Scandinavia support important populations of many wetland bird species (Arvidsson et al. 1992).

A representative sample of mires $(n=19)$ in southeastern Norway was censused in 1976-77 (Hardeng 2014, G. Hardeng unpublished material). Nearly all of the mires are still intact today $(n=18)$, partly because many became protected as nature reserves $(\mathrm{n}=15)$. Thus, this sample can provide information on population changes that are not due to human-caused habitat loss or habitat change in the breeding areas. We recensused the mires in 2015 and analysed population changes of individual species and for the whole bird community. Because long-distance migrants are 


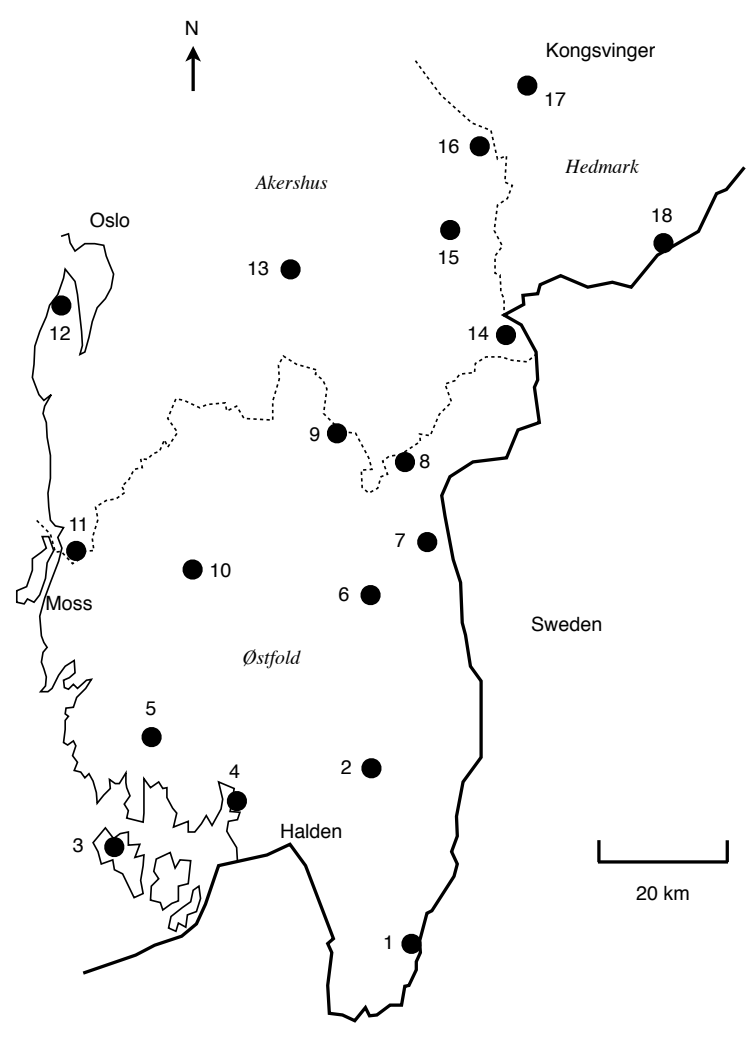

Figure 1. Map of study area with location of the 18 mires included in the study. Thick solid line $=$ border to Sweden. Thin solid line $=$ coast line. Stippled lines $=$ county boundaries. Numbers refer to site IDs in Appendix 1. Sites 3, 4, 5, 11 and 12 are located in the boreo-nemoral zone, all other sites are in the boreal zone.

declining, we also compared groups of species with different migratory strategies. Furthermore, both in 1976-77 and 2015 birds in the forests surrounding the mires were recorded. We analysed changes in the forest bird community and compared population changes of species in forest to those of species in mire habitat. Finally, because birds in agricultural areas in Europe are declining, we compared population changes of short-distance migrants wintering in agricultural habitats to those of species wintering in other habitats (wetland, forest).

\section{METHODS}

\section{Study area}

Nineteen mires in Østfold ( $\mathrm{n}=11)$, Akershus $(\mathrm{n}=6)$ and Hedmark $(\mathrm{n}=2)$ counties in southeastern Norway were censused during 1976-77. One mire in Østfold has later been destroyed, whereas the remaining 18 mires are still intact and were recensused in 2015 (15 have become nature reserves; Figure 1, Appendix 1). The mires are located in the boreo-nemoral zone (n $=5)$ and the southern boreal zone $(\mathrm{n}=13)$, and were selected to provide a representative sample of intact mires spanning different elevations (range 45-420 m a.s.l., median $165 \mathrm{~m}$ a.s.l.; Appendix 1), sizes (range 4.3-63.5 ha, median 21.6 ha; Appendix 1), regions having both high and low proportion of mires in the landscape, and different mire types. Mires varied from dry to wet (13 had at least small ponds), and some had patches of forest. Mire vegetation types varied from ombrotrophic bog to poor and intermediate fen (types $\mathrm{J}, \mathrm{K}$ and $\mathrm{L}$ in the Norwegian vegetation classification system; Fremstad 1997). Most of the sites were mixed mires, but with dominance of ombrotrophic vegetation types. The total area censused on the 18 mires was 534 ha. The distances between neighbouring bogs were at least $10.0 \mathrm{~km}$.

Mires were generally surrounded by boreal forest dominated by Norway spruce Picea abies, Scots pine Pinus sylvestris and downy birch Betula pubescens. Except for small areas of forest bordering the bogs, most of the surrounding forests were not under protection and were generally managed for timber production so that habitat conditions may have changed between 1976-77 and 2015. We use the term 'site' when referring to one mire and the forest surrounding that mire.

\section{Censuses}

Censuses were done by walking slowly along lines set out to cover all parts of the mires. For smaller sites census lines crossed or circled mires, for larger sites census lines could follow zig-zag lines to ensure that no parts of mires were $>100 \mathrm{~m}$ from the census lines (see Hardeng 2014 for map of census lines on two of the mires). Censuses usually started around sunrise and lasted 40-305 min (median $123 \mathrm{~min}$ ). Median start time (Norwegian summer time) was $04.45 \mathrm{~h}$ and median end time was $06.45 \mathrm{~h}$ (latest $10.15 \mathrm{~h}$ ). Time spent censusing increased with size of mire (1976-77: $\left.r_{s}=0.75, p=0.002 ; 2015: r_{s}=0.80, p=0.001\right)$. All censuses were done in favourable weather during the peak of the breeding season (see further below). During censuses all birds observed on mires were recorded and their positions and behaviour were noted on maps. Particular care was taken to distinguish between multiple territories of the same species and multiple observations of the same individuals.

In addition to the main focus on the bird community on the mires, all birds heard or seen in the forests surrounding the mires when walking census lines on the mires were noted without any distance limitations. Limitless census of forest species may bias their relative abundance so that less vocal and less active species are undersampled. However, this should not affect 
the main purpose of our study, which was to assess changes in relative abundance within species between the two census periods (see further in the Discussion). However, our data on total abundance of forest birds (total number of individuals summed across species) should be taken as a gross estimate because the data represent the more vocal and active species subset of the bird community.

The time spent censusing mires was shorter in 2015 than in 1976-77 (mean \pm SE in 1976-77: $148 \pm 17$ $\min , 2015: 107 \pm 12 \mathrm{~min}$; paired t-test, $\mathrm{t}=3.17$, $\mathrm{df}=$ $17, \mathrm{p}=0.006)$. One could argue that this might have created a bias so that species and individuals were missed to some degree in 2015. However, we note that the number of individuals observed was actually higher in 2015 (see Results), and the number of species observed was lower in only one of the habitats (mire, see Results). Importantly, there were no relationships indicating that the difference in number of species and individuals observed between 1976-77 and 2015 was related to the difference in time spent censusing (time difference varied between $135 \mathrm{~min}$ less to $50 \mathrm{~min}$ more in 2015; Pearson correlation analyses: time difference versus difference in number of mire species: $r=0.13$, $\mathrm{p}=0.62$; time difference versus difference in number of mire individuals: $r=0.18, p=0.49$; time difference versus difference in number of forest species: $r=0.27$, $\mathrm{p}=0.27$; time difference versus difference in number of forest individuals: $r=0.13, p=0.60)$. Thus, we conclude that difference in census time did not have major influence on number of species or individuals observed. In all censuses, we spent a reasonable amount of time on the mires in order to detect species and individuals present. Note also that for 12 out of the 18 mires, the the time spent censusing per ha was higher in 2015 than the lower value for 1976-77, indicating a considerable overlap in census effort between the two time periods.

Bird censuses done in 2015 (one per site) were compared to censuses done during 1976-77. During 1976-77, each site was originally censused 2-7 times (two censuses: $\mathrm{n}=2$; three censuses: $\mathrm{n}=13$; four censuses: $\mathrm{n}=1$; seven censuses: $\mathrm{n}=2$; total 61 censuses). For comparisons we selected one census per site from 1976-77 on the basis of the timing of the censuses. First, we excluded all censuses from 1976-77 that were made before the first census made in 2015 (20 May, $\mathrm{n}=8$ ). Next, we excluded censuses made after 10 June $(n=27)$ because the last census in 2015 was made 4 June and because after 10 June would be considered late in the breeding season even in 197677. For sites that had $\geq 2$ censuses remaining $(n=6)$, we considered that effects of climate change (earlier arrival to breeding areas and earlier breeding: e.g. Crick \& Sparks 1999, Walther et al. 2002) would make comparisons using a later census from 1976-77 than from 2015 most relevant. Thus, we excluded censuses made earlier in 1976-77 than the corresponding census in $2015(\mathrm{n}=5)$. Finally, for the two sites that had $\geq$ 2 censuses remaining we chose the one that matched most closely the deviance in date between 1976-77 and 2015 for the other sites (censuses were done a median of 9 days earlier in 2015 than in 1976-77: median dates 26 May versus 3 June).

All censuses in 1976-77 were done by GH, whereas censuses in 2015 were done by GH $(n=6)$ and SD (n $=12$ ). We did not find any evidence that changes in the bird community from 1976-77 to 2015 depended on who did censuses in 2015 (changes in number of mire species: unpaired t-test: $\mathrm{t}=0.00, \mathrm{p}=1.00$, changes in number of mire individuals: $\mathrm{t}=0.90, \mathrm{p}=0.38$, changes in number of forest species: $t=1.02, p=0.32$, changes in number of forest individuals: $\mathrm{t}=1.56, \mathrm{p}=0.14$ ). Thus, observer identity was not included in analyses of data, in line with results from Enemar et al. (1978).

\section{Mire and forest species}

Mire species $(n=29)$ were species that were observed on the mires and that used mires during the breeding season for nesting, feeding or lekking. Most species used mires for both nesting and feeding, whereas Black Grouse used mires mainly for lekking. For some species (e.g. some ducks, Common Redshank Tringa totanus, Red-throated Pipit Anthus cervinus, Northern Wheatear Oenanthe oenanthe, Great Grey Shrike Lanius excubitor, breeding on the mires was uncertain, and observed individuals may have been non-breeders. Forest species $(n=54)$ were all other bird species seen or heard in the forests surrounding the mires, both territorial and overflying individuals. This also included a few species that breed neither in the forest nor on the mires (e.g. Barn Swallow Hirundo rustica). See Appendix 2 for classification of mire and forest species.

\section{Migratory status}

Mire and forest species observed in $\geq 3$ sites $(\mathrm{n}=57)$ were classified into three groups according to migratory status: residents $(n=16)$ were species wintering in or close to study sites, short-distance migrants $(n=26)$ were species wintering within Europe, whereas longdistance migrants $(\mathrm{n}=15)$ were species wintering predominantly in Africa (based on Cramp et al. 197794, Dale et al. 2001; see also Appendix 2). Among mire species, there was only one species that was classified as resident (Black Grouse Tetrao tetrix). Thus, analyses of migratory status for mire species compared only short-distance migrants with long-distance migrants, whereas analyses of forest species compared all three groups of species. 


\section{Winter habitat}

The winter habitat of short-distance migrants (both mire and forest species) was classified as wetland ( $\mathrm{n}=$ $5)$, agricultural areas $(n=13$; including species that use this habitat commonly during winter, although other habitats may also be used) or forest ( $\mathrm{n}=8$; including other terrestrial habitats with cover; see Appendix 2) according to Birds of the Western Palearctic (Cramp et al. 1977-94) and Wilson et al. (1996). Species wintering in agricultural areas were compared to species wintering in other habitats (wetland and forest combined).

\section{Importance of mires as breeding habitat}

To test whether population change was associated with how important mires were as breeding habitat for individual species, we used data from Arvidsson et al. (1992; Table 2) who presented estimates of how large proportion of the total Swedish population of some wetland species used mires as breeding habitat.

\section{Statistical analyses}

Based on the field data, the total number of territories (singing males or other forms of territoriality) or pairs of each species in each site was determined. However, for some species we regarded it difficult to assess territories or pairs based on the field observations, and instead we chose to use number of individuals observed in analyses. This was the case in particular for ducks, gulls and some passerines (e.g. swallows, corvids and some finches that were usually seen overflying), see Table 1 and 2 for unit used for each species. Changes in abundance of individual species were compared with Wilcoxon signed-ranks tests of the changes in numbers within each site between 1976-77 and 2015 (see Appendix 3 for a comparison of the performance of three alternative tests of changes in abundance). Tests were possible for all species with a population change in $\geq 4$ sites. Changes for individual species were considered significant when $\mathrm{p} \leq 0.05$, and near significant when $0.10>p>0.05$. Tests were made for 15 mire species and 33 forest species. In cross-species analyses of population changes in relation to ecological variables (migration, habitat; see below) a larger set of species was used, including all species that had been recorded in $\geq 3$ sites (both census periods combined; 20 mire species and 37 forest species). Analyses of population changes were made using 1) relative change in abundance (numbers in 2015 as percentage of numbers in 1976-77), or 2) categorical classification of species as decreasing ( $>50 \%$ decrease in abundance), stable $(\leq 50 \%$ population change), or increasing $(>$
$50 \%$ increase in abundance).

Our estimates of population changes were based on censuses done at two time periods 40 years apart. To assess to what degree they were likely to represent long-term trends, and not just year-to-year variation in population size, we made comparisons with population changes in consecutive years (within 1975-77 (Geir Hardeng, unpublished data) and between 2014 (Hardeng 2014) and 2015 (this study), see further in Appendix 4).

Changes in number of species within each site between 1976-77 and 2015 were compared with paired t-tests. For analyses of changes in abundance (total number of individuals recorded) in each habitat (mire, forest or both combined), we calculated the total number of individuals observed in each site as the sum of number of territories/pairs (for species reported with unit $=1$ in Table 1 and 2) multiplied with two, plus the number of individuals (for species reported with unit $=$ 2 in the same tables). Changes in total abundance of all species were analysed with paired t-tests.

The relationships between migratory status (resident, short distance migrant, long-distance migrant) and population changes (decreasing, stable, increasing) were analysed with Fisher exact tests or chi-square tests $(2 \times 3$ for mire species, $3 \times 3$ for forest species and all species combined). Tests included species that were present in $\geq 3$ sites. For forest species and all species combined, we also combined short- and long-distance migrants in order to compare residents with all migrants. The relationships between migratory status and changes in abundance ( $\%$ population change) were analysed with Mann-Whitney U-tests (mires) or Kruskal-Wallis tests (surrounding forests and all species combined). Tests included species that were recorded in $\geq 3$ sites. Similarly, comparisons of mire and forest species were done with chi-square test (population change scored as decreasing, stable, increasing) and Mann-Whitney U-test (change in abundance), and analyses of winter habitat (agricultural areas versus other habitats) were done with Fisher exact test (population change scored as decreasing, stable, increasing) and Mann-Whitney U-test (change in abundance).

\section{RESULTS}

\section{Mires}

We found significant population changes in 8 out of 15 bird species that had sufficient data for analyses (53\%, Table 1). Four species had significant increases (Table 1): Red-throated Diver Gavia stellata (+200\%), Common Crane Grus grus (+400\%), Wood Sandpiper Tringa glareola $(+130 \%)$ and Tree Pipit Anthus trivialis $(+53 \%)$. Four species had significant declines (Table 1): Northern Lapwing Vanellus vanellus (- 77\%), Black- 
headed Gull Chroicocephalus ridibundus (extinct), Meadow Pipit Anthus pratensis (-86\%) and Yellow Wagtail Motacilla flava (-75\%). There were also near significant $(\mathrm{p}=0.06)$ decreases of Eurasian Curlew Numenius arquata (-55\%) and Eurasian Skylark Alauda arvensis (extinct) (Table 1). Four species were stable ( $\leq 50 \%$ population change; Table 1$)$ : Mallard Anas platyrhynchos $(+50 \%)$, Common Gull Larus canus $(-27 \%)$, White Wagtail Motacilla alba (-26\%) and Whinchat Saxicola rubetra $(+45 \%)$. Overall, there was a significant $19 \%$ decline in mean number of species on each mire (paired t-test: $\mathrm{t}=3.17, \mathrm{df}=17, \mathrm{p}$ $=0.0055$; Figure 2), but a non-significant $7 \%$ increase in mean number of individuals on each mire $(\mathrm{t}=0.95$, $\mathrm{df}=17, \mathrm{p}=0.35$; Figure 2).

There was no difference between short-distance and long-distance migrants in number of species showing positive or negative population changes (Fisher exact $2 \times 3$ test: $p=1.00$; including all species recorded in $\geq 3$ sites; Figure 3 ). Short-distance and long-distance migrants did not differ significantly with respect to changes in abundance (13 short-distance migrants had a median of $26 \%$ decrease, 6 long-distance migrants had a median of $13 \%$ decrease; Mann-Whitney U-test: $\mathrm{z}=0.53, \mathrm{p}=0.60$; including all species recorded in $\geq$ 3 sites).

\section{Surrounding forests}

There were significant population changes in 14 out of 33 bird species for which we had sufficient data for

Table 1. Changes in abundance of bird species on 18 mires in southeastern Norway between 1976-77 and 2015. P-values are from Wilcoxon signed-ranks test of sites which had a change in numbers, and are given only when there were data for at least four sites. Significant results are in bold.

\begin{tabular}{|c|c|c|c|c|c|c|c|c|}
\hline \multirow[b]{2}{*}{ Species $^{1}$} & \multirow[b]{2}{*}{ Unit $^{2}$} & \multicolumn{2}{|c|}{$\begin{array}{l}\text { Numbers } \\
\text { observed }\end{array}$} & \multicolumn{3}{|c|}{ Number of sites with: } & \multirow[b]{2}{*}{$\mathrm{p}$} & \multirow[b]{2}{*}{ Change } \\
\hline & & 1976-77 & 2015 & Decline & $\begin{array}{c}\text { No } \\
\text { change }\end{array}$ & Increase & & \\
\hline Whooper Swan Cygnus cygnus & 1 & 0 & 2 & 0 & 0 & 2 & - & \\
\hline Common Teal Anas crecca & 2 & 0 & 8 & 0 & 0 & 3 & - & $(+)$ \\
\hline Mallard Anas platyrhynchos & 2 & 12 & 18 & 4 & 2 & 3 & 0.86 & 0 \\
\hline Common Goldeneye Bucephala clangula & 2 & 2 & 5 & 0 & 2 & 2 & - & $(+)$ \\
\hline Black Grouse Tetrao tetrix & 2 & 14 & 46 & 2 & 0 & 6 & 0.12 & $(+)$ \\
\hline Red-throated Diver Gavia stellata & 1 & 2 & 6 & $\mathbf{0}$ & 1 & 4 & 0.046 & + \\
\hline Common Crane Grus grus & 1 & 2 & 10 & $\mathbf{0}$ & 2 & 8 & 0.005 & + \\
\hline European Golden Plover Pluvialis apricaria & 1 & 4 & 8 & 0 & 1 & 3 & - & $(+)$ \\
\hline Northern Lapwing Vanellus vanellus & 1 & 13 & 3 & 7 & 2 & $\mathbf{0}$ & 0.014 & - \\
\hline Eurasian Curlew Numenius arquata & 1 & 11 & 5 & 6 & 1 & 1 & 0.06 & - \\
\hline Common Sandpiper Actitis hypoleucos & 1 & 4 & 0 & 3 & 0 & 0 & - & $(-)$ \\
\hline Green Sandpiper Tringa ochropus & 1 & 2 & 0 & 2 & 0 & 0 & - & \\
\hline Green Sandpiper (overflying) & 2 & 3 & 2 & 1 & 2 & 0 & - & $(-)$ \\
\hline Wood Sandpiper Tringa glareola & 1 & 10 & 23 & $\mathbf{0}$ & 2 & 8 & 0.008 & + \\
\hline Common Snipe Gallinago gallinago & 1 & 2 & 0 & 2 & 0 & 0 & - & \\
\hline Black-headed Gull Chroicocephalus ridibund & dus 2 & 17 & $\mathbf{0}$ & 5 & $\mathbf{0}$ & $\mathbf{0}$ & 0.041 & - \\
\hline Common Gull Larus canus & 2 & 26 & 19 & 4 & 0 & 2 & 0.34 & 0 \\
\hline Eurasian Skylark Alauda arvensis & 1 & 8 & 0 & 4 & 0 & 0 & 0.06 & - \\
\hline Tree Pipit Anthus trivialis & 1 & 60 & 92 & 3 & 4 & 11 & 0.010 & + \\
\hline Meadow Pipit Anthus pratensis & 1 & 22 & 3 & 11 & $\mathbf{0}$ & $\mathbf{0}$ & 0.003 & - \\
\hline Yellow Wagtail Motacilla flava & 1 & 16 & 4 & 6 & $\mathbf{0}$ & 1 & 0.040 & - \\
\hline White Wagtail Motacilla alba & 2 & 23 & 17 & 7 & 5 & 3 & 0.25 & 0 \\
\hline Whinchat Saxicola rubetra & 1 & 11 & 16 & 2 & 1 & 4 & 0.40 & 0 \\
\hline
\end{tabular}

${ }^{1}$ Species with $\leq 2$ individuals or $\leq 1$ territory/pair observed both in 1976-77 and 2015 are excluded from the table: One individual/territory recorded in each period: Common Redshank Tringa totanus, Northern Wheatear Oenanthe oenanthe; one individual/territory recorded in the first period, none in the second: Goosander Mergus merganser, Red-throated Pipit Anthus cervinus, Reed Bunting Emberiza schoeniclus; one individual/territory recorded in the second period, none in the first: Canada Goose Branta canadensis, Great Grey Shrike Lanius excubitor.

${ }^{2} 1=$ Territories/pairs, 2 = individuals.

3 +/-: significant increase/decrease; +/-: near significant increase/decrease; 0 : stable; $(+) /(-)$ : changes for other species used in cross-species analyses (species which had non-significant tests, or too few sites for statistical testing, but occurred in $\geq 3$ sites). Change was classified as decreasing ( $>50 \%$ decrease in abundance), stable ( $\leq 50 \%$ population change), or increasing $(>50 \%$ increase in abundance). 


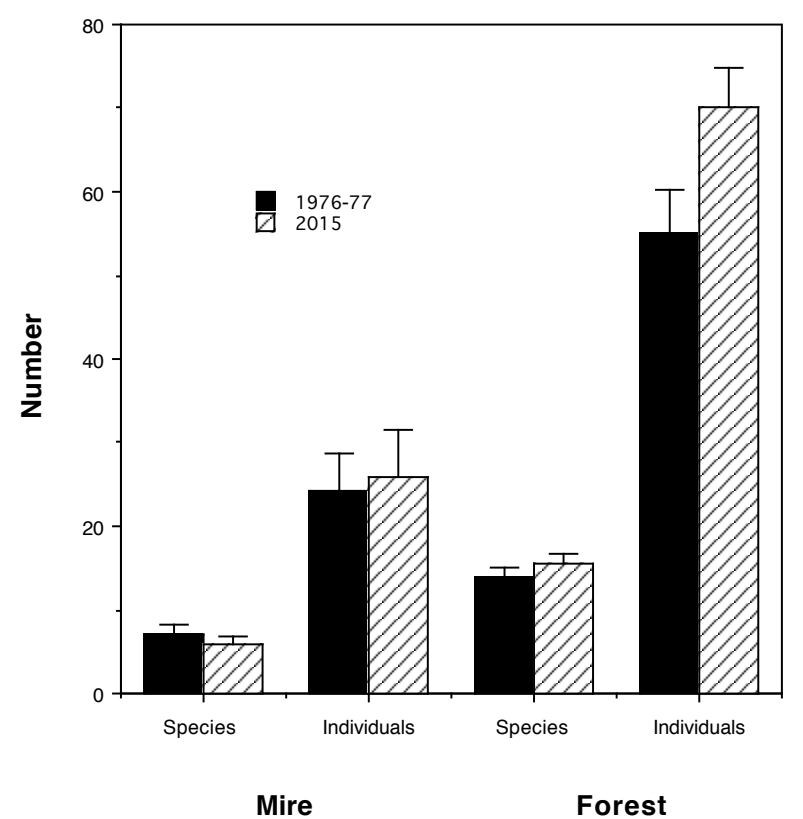

Figure 2. Changes in number of bird species and number of individuals on 18 mires and in surrounding forests in southeastern Norway between 1976-77 and 2015. Bars show means $\pm \mathrm{SE}$.

analyses ( $42 \%$, Table 2$)$. There were nearly significant changes in a further five species (Table 2). In total, there were eight species with negative changes and 11 species with positive changes (Table 2). Overall, there was a non-significant $12 \%$ increase in number of species in forests around each mire (paired t-test: $\mathrm{t}=$ $1.26, \mathrm{df}=17, \mathrm{p}=0.23$; Figure 2), and a significant $28 \%$ increase in number of individuals in forests around each mire $(t=2.36, d f=17, p=0.031$; Figure 2).

Comparing species with different migratory strategies, we found that only one resident species showed a population decrease and that only two longdistance migrants showed population increases, but this pattern was not significant (Fisher exact $3 \times 3$ test: $p=0.14$; including all species recorded in $\geq 3$ sites; Figure 4). There was no overall difference in changes in abundance in relation to migratory strategy (KruskalWallis test: $\mathrm{H}=3.46, \mathrm{n}=37, \mathrm{p}=0.18$; including all species recorded in $\geq 3$ sites). Comparing resident species with short- and long-distance migrants combined, there was a non-significant trend that residents had more positive changes in abundance than migrants (15 resident species had a median of $75 \%$ increase, 22 migrants had a median decrease of $3 \%$; Mann-Whitney U-test: $\mathrm{z}=1.59, \mathrm{p}=0.11$ ).

\section{Mire species versus forest species}

Mire-associated and forest-associated species did not differ in population changes (mire species $(n=20): 8$

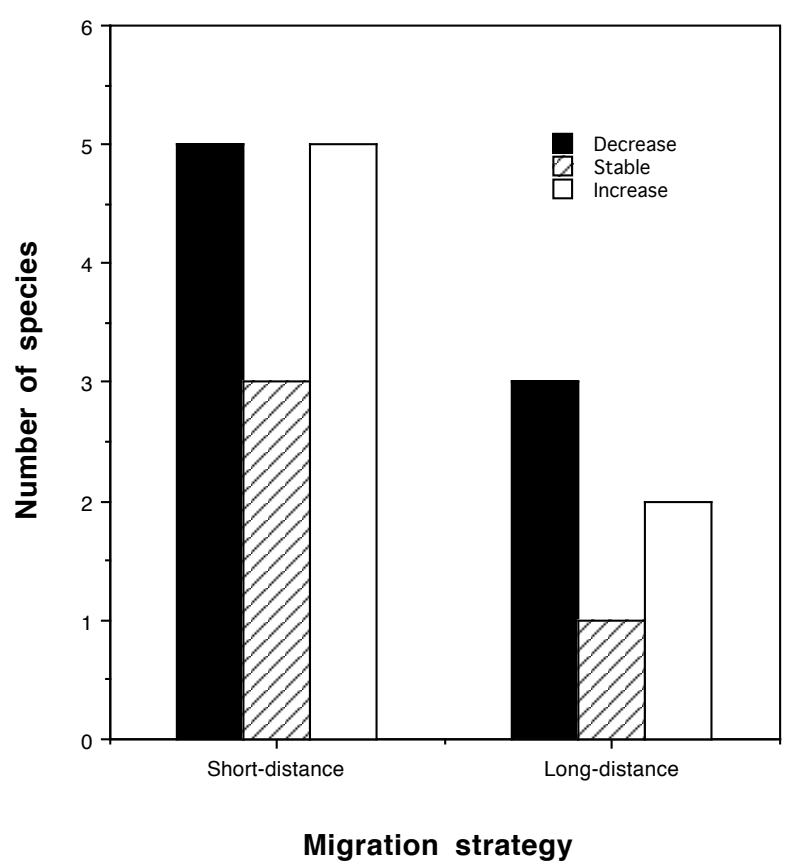

Figure 3. Relationship between migration strategy and population changes of bird species $(n=19)$ on mires in southeastern Norway between 1976-77 and 2015.

declined, 4 were stable, 8 increased; forest species ( $\mathrm{n}=$ 37): 9 declined, 12 were stable, 16 increased; $\chi^{2}=1.82$, $\mathrm{df}=2, \mathrm{p}=0.40$; including all species recorded in $\geq 3$ sites). Further, mire and forest species showed similar changes in abundance (20 mire species had a median of

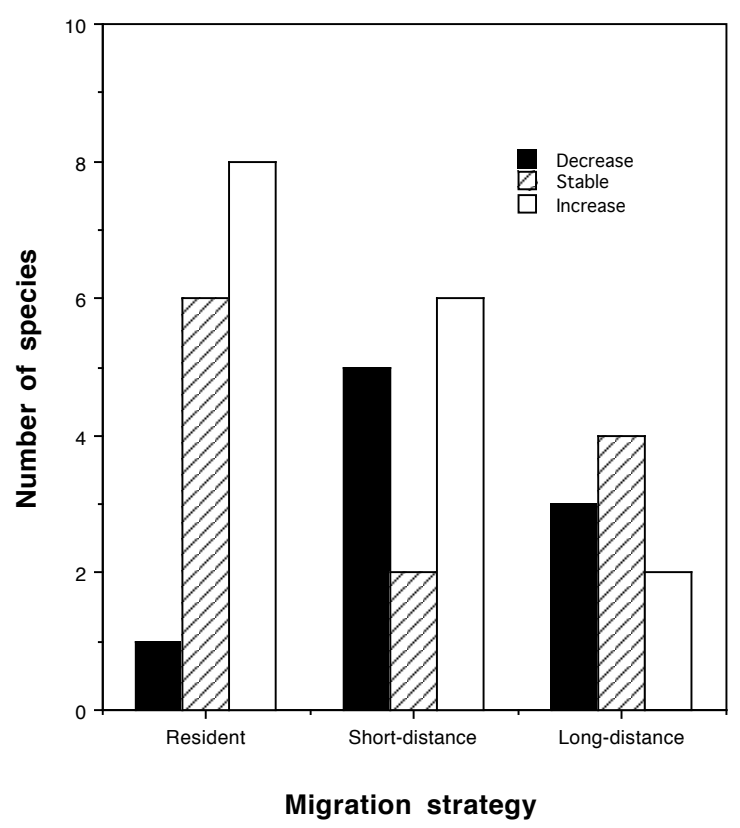

Figure 4. Relationship between migration strategy and population changes of bird species $(n=37)$ in forests surrounding mires in southeastern Norway between 1976-77 and 2015 . 
Table 2. Changes in abundance of bird species in forests surrounding 18 mires in southeastern Norway between 1976-77 and 2015. P-values are from Wilcoxon signed-ranks test of sites which had a change in numbers, and are given only when there were data for at least four sites. Significant results are in bold.

\begin{tabular}{|c|c|c|c|c|c|c|c|c|}
\hline \multirow[b]{2}{*}{ Species $^{1}$} & \multirow[b]{2}{*}{ Unit $^{2}$} & \multicolumn{2}{|c|}{$\begin{array}{l}\text { Numbers } \\
\text { observed }\end{array}$} & \multicolumn{3}{|c|}{ Number of sites with: } & \multirow[b]{2}{*}{$\mathrm{p}$} & \multirow[b]{2}{*}{ Change ${ }^{3}$} \\
\hline & & $1976-77$ & 2015 & Decline & $\begin{array}{c}\text { No } \\
\text { change }\end{array}$ & Increase & & \\
\hline Common Woodpigeon Columba palumbus & 2 & 30 & 14 & 9 & 6 & 2 & 0.022 & - \\
\hline Common Cuckoo Cuculus canorus & 1 & 15 & 18 & 4 & 6 & 6 & 0.41 & 0 \\
\hline Eurasian Wryneck Jynx torquilla & 1 & 4 & 0 & 2 & 0 & 0 & - & \\
\hline Black Woodpecker Dryocopus martius & 1 & 4 & 5 & 4 & 0 & 5 & 0.74 & 0 \\
\hline Great Spotted Woodpecker Dendrocopos major & 1 & 4 & 5 & 2 & 1 & 3 & 0.78 & 0 \\
\hline Wood Lark Lullula arborea & 1 & 0 & 3 & 0 & 0 & 3 & - & $(+)$ \\
\hline Barn Swallow Hirundo rustica & 2 & 4 & 9 & 2 & 1 & 4 & 0.24 & $(+)$ \\
\hline Eurasian Wren Troglodytes troglodytes & 1 & 2 & 11 & 2 & 0 & 6 & 0.08 & + \\
\hline Dunnock Prunella modularis & 1 & 17 & 3 & 7 & 1 & 1 & 0.028 & - \\
\hline European Robin Erithacus rubecula & 1 & 23 & 46 & 5 & $\mathbf{0}$ & 11 & 0.049 & + \\
\hline Common Redstart Phoenicurus phoenicurus & 1 & 15 & 9 & 7 & 3 & 2 & 0.20 & 0 \\
\hline Common Blackbird Turdus merula & 1 & 11 & 10 & 6 & 0 & 7 & 0.77 & 0 \\
\hline Fieldfare Turdus pilaris & 2 & 14 & 2 & 8 & $\mathbf{0}$ & 1 & 0.018 & - \\
\hline Song Thrush Turdus philomelos & 1 & 14 & 28 & 3 & 3 & 9 & 0.06 & + \\
\hline Redwing Turdus iliacus & 1 & 1 & 6 & 0 & 0 & 4 & 0.06 & + \\
\hline Mistle Thrush Turdus viscivorus & 1 & 1 & 18 & $\mathbf{0}$ & $\mathbf{0}$ & 13 & 0.0009 & + \\
\hline Lesser Whitethroat Sylvia curruca & 1 & 8 & $\mathbf{0}$ & 7 & $\mathbf{0}$ & $\mathbf{0}$ & 0.011 & - \\
\hline Garden Warbler Sylvia borin & 1 & 7 & 1 & 4 & 1 & 0 & 0.06 & - \\
\hline Willow Warbler Phylloscopus trochilus & 1 & 77 & 94 & 6 & 0 & 12 & 0.27 & 0 \\
\hline Goldcrest Regulus regulus & 1 & 5 & 18 & $\mathbf{0}$ & 2 & 10 & 0.003 & + \\
\hline Spotted Flycatcher Muscicapa striata & 1 & 2 & 9 & 1 & 1 & 4 & 0.07 & + \\
\hline European Pied Flycatcher Ficedula hypoleuca & 1 & 6 & 4 & 3 & 1 & 2 & 0.58 & 0 \\
\hline Blue Tit Cyanistes caeruleus & 1 & $\mathbf{0}$ & 7 & $\mathbf{0}$ & $\mathbf{0}$ & 5 & 0.038 & + \\
\hline Great Tit Parus major & 1 & 21 & 47 & 2 & 2 & 14 & 0.002 & + \\
\hline Coal Tit Periparus ater & 1 & 3 & 2 & 2 & 1 & 1 & - & $(0)$ \\
\hline Crested Tit Lophophanes cristatus & 1 & 11 & 13 & 4 & 2 & 8 & 0.81 & 0 \\
\hline Willow Tit Poecile montanus & 1 & 10 & 8 & 3 & 4 & 3 & 0.52 & 0 \\
\hline Eurasian Treecreeper Certhia familiaris & 1 & $\mathbf{0}$ & 9 & $\mathbf{0}$ & $\mathbf{0}$ & 7 & 0.011 & + \\
\hline Red-backed Shrike Lanius collurio & 1 & 7 & $\mathbf{0}$ & 7 & $\mathbf{0}$ & $\mathbf{0}$ & 0.008 & - \\
\hline Eurasian Jay Garrulus glandarius & 2 & 4 & 7 & 3 & 0 & 5 & 0.56 & $(+)$ \\
\hline Hooded Crow Corvus cornix & 2 & 28 & 10 & 8 & 2 & 3 & 0.025 & - \\
\hline Common Starling Sturnus vulgaris & 2 & 3 & 0 & 1 & 0 & 0 & - & \\
\hline Common Chaffinch Fringilla coelebs & 1 & 112 & 115 & 7 & 3 & 8 & 0.75 & 0 \\
\hline Brambling Fringilla montifringilla & 1 & 4 & 0 & 3 & 0 & 0 & - & $(-)$ \\
\hline Eurasian Siskin Spinus spinus & 2 & 28 & 87 & 2 & 1 & 15 & 0.002 & + \\
\hline Common Redpoll Acanthis flammea & 2 & 2 & 4 & 1 & 0 & 3 & 0.32 & $(+)$ \\
\hline Crossbills Loxia spp. & 2 & 55 & 129 & 6 & 0 & 12 & 0.13 & $(+)$ \\
\hline Eurasian Bullfinch Pyrrhula pyrrhula & 1 & 2 & 2 & 1 & 1 & 1 & - & $(0)$ \\
\hline Yellowhammer Emberiza citrinella & 1 & 19 & 2 & 7 & 1 & 0 & 0.017 & - \\
\hline
\end{tabular}

${ }^{1}$ Species with $\leq 2$ individuals or $\leq 1$ territory/pair observed both in 1976-77 and 2015 are excluded from the table: One individual/territory recorded in each period: Common Buzzard Buteo buteo, Osprey Pandion haliaetus, Blackcap Sylvia atricapilla, Common Raven Corvus corax; one individual/territory recorded in the first period, none in the second: Common Kestrel Falco tinnunculus, Tengmalm's Owl Aegolius funereus, Sand Martin Riparia riparia, Common Magpie Pica pica, European Greenfinch Chloris chloris; one individual/territory recorded in the second period, none in the first: Eurasian Hobby Falco subbuteo, Common Swift Apus apus, Grey-headed Woodpecker Picus canus, European Green Woodpecker Picus viridis, Icterine Warbler Hippolais icterina, Eurasian Nuthatch Sitta europaea.

${ }^{2} 1=$ Territories/pairs, 2 = individuals.

${ }^{3}+/$ : : significant increase/decrease; +/-: near significant increase/decrease; 0 : stable; $(+) /(0) /(-)$ : change for other species used in cross-species analyses (species which had non-significant tests, or too few sites for statistical testing, but occurred in $\geq 3$ sites). Change was classified as decreasing ( $>50 \%$ decrease in abundance), stable ( $\leq 50 \%$ population change), or increasing $(>50 \%$ increase in abundance). 
$10 \%$ increase, 37 forest species had a median of $22 \%$ increase; Mann-Whitney U-test: $\mathrm{z}=0.71, \mathrm{p}=0.48$; including all species recorded in $\geq 3$ sites).

\section{Migration strategy}

Combining mire and forest species showed a pattern that resident species had more positive changes than short- and long-distance migrants (Fisher exact $3 \times 3$ test: $p=0.10)$. The contrast was significant when resident species were compared to all migrant species (resident species $(\mathrm{n}=16)$ : 1 declined, 6 were stable, 9 increased; migratory species $(n=41)$ : 16 declined, 10 were stable, 15 increased; Fisher exact $2 \times 3$ test: $p$ $=0.039$ ). Similarly, changes in abundance were nearly significantly related to migratory status, with residents having generally more positive changes than shortand long-distance migrants (Kruskal-Wallis test: $\mathrm{H}=$ 5.23, $\mathrm{n}=57, \mathrm{p}=0.07)$. Changes in abundance were significantly related to migratory status when comparing residents with all migrants (16 resident species had a median of $88 \%$ increase whereas 41 migratory species had a median of $9 \%$ decrease; Mann-Whitney U-test: $\mathrm{z}$ $=2.03, \mathrm{p}=0.043$ ).

\section{Wintering habitat}

Among short-distance migrants, there was a nonsignificant trend that species wintering in agricultural areas had decreasing populations ( 7 out of 13 species) more often than species wintering in other habitats (3 out of 13 species wintering in wetland or forest; Fisher exact $2 \times 3$ test: $p=0.13$ ). Species wintering in agricultural areas had significantly more negative changes in abundance than species wintering in other habitats (13 species wintering in agricultural areas had a median of $53 \%$ decrease, 13 species wintering in other habitats had a median of $100 \%$ increase; MannWhitney U-test: $\mathrm{z}=-2.08, \mathrm{p}=0.038$ ).

\section{Importance of mires as breeding habitat}

For mire species, there was a positive correlation between changes in abundance and the proportion of the Swedish population that used mires as breeding habitat $\left(\mathrm{r}_{\mathrm{s}}=0.65, \mathrm{n}=16, \mathrm{p}=0.012\right.$; Figure 5).

\section{DISCUSSION}

\section{Mire species}

Overall, we found a $19 \%$ decline in number of bird species on the 18 mires during the last 40 years. On

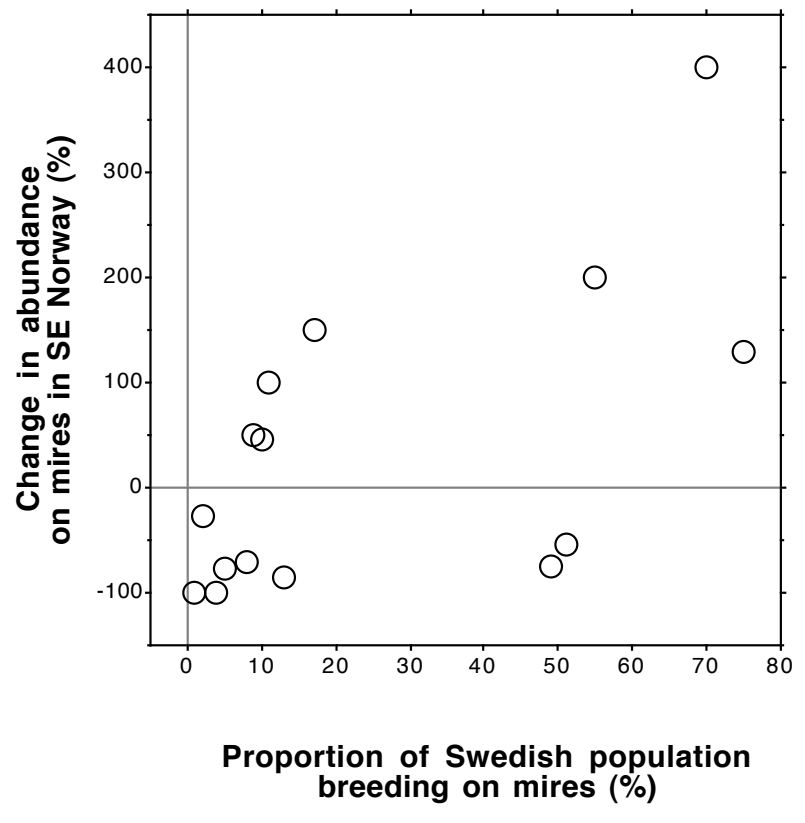

Figure 5. Relationship between population change (change in abundance between 1976-77 and 2015) of 15 bird species on mires in southeastern Norway, and importance of mires as breeding habitat (proportion of Swedish population breeding on mires taken from Arvidsson et al. 1992). The figure excludes one data point with 'infinite' increase (common teal increased from 0 to 8 individuals in Norway, and had $26 \%$ of population on mires in Sweden).

average, the number of species on each mire declined from 7.2 to 5.8 . The decline in species numbers was due to large declines of at least six species (Northern Lapwing, Eurasian Curlew, Black-headed Gull, Eurasian Skylark, Meadow Pipit and Yellow Wagtail), of which two disappeared completely (Black-headed Gull, Eurasian Skylark). Northern Lapwing disappeared from 7 out of 9 previously used mires, Eurasian Curlew from 5 out of 8 mires, Meadow Pipit from 8 out of 11 mires and Yellow Wagtail from 4 out of 7 mires. Negative trends for many of these species have also been noted in previous studies in other habitats or in large-scale population monitoring (Northern Lapwing: Byrkjedal et al. 2012, Heggøy \& Øien 2014; Eurasian Curlew: de Jong \& Berg 2001, Shimmings \& Øien 2015; Black-headed Gull: Breistøl \& Helberg 2012, Andersen \& Bergan 2013; Meadow Pipit: Byrkjedal \& Kålås 2012, Lehikoinen et al. 2014; general surveys: Green \& Lindström 2014, Kålås et al. 2014). Our study had limited data on some other species so that statistical tests were not possible, but we note that also the Common Sandpiper Actitis hypoleucos and the Common Snipe Gallinago gallinago appeared to have become extinct at the study sites in 2015 .

On the other hand, we also found major increases for at least four species. For two of these species (Redthroated Diver and Common Crane), increases have also been reported previously (Fredriksen et al. 2011, Green 
\& Lindström 2014, Shimmings \& Øien 2015). We also note that the well-known increase of Whooper Swans Cygnus cygnus in Scandinavia (Green \& Lindström 2014, Nilsson 2014, Shimmings \& Øien 2015) had led to colonization of mires in our study area as well (though only present in two sites so far). However, for the other two species with significant population increase (Wood Sandpiper and Tree Pipit), similar changes have not been seen in general surveys at larger spatial scales (Green \& Lindström 2014, Kålås et al. 2014). This indicates that there may be spatial variation in population trends in some species with changes in our study area differing from nation-wide trends. One could argue that increases of some mire species in our study sites (mostly protected areas) may have been due to immigration from mires that have been drained or destroyed for other reasons. However, it appears unlikely that draining of mires should lead to long-term population increases on undrained mires up to 40 years later. We think it is more likely that habitat loss simply leads to a reduction of population size. Furthermore, to our knowledge relatively few open mires have been drained in our study area during this 40-year period.

Overall, the bird community on the mires in southeastern Norway has shown a considerable turnover during the last fourty years. However, this is unlikely to represent natural variations because many of the largest population changes may be linked to human activities (e.g. Donald et al. 2001, Prange 2005, Breistøl \& Helberg 2012, Heggøy \& Øien 2014). Given steadily increasing human pressure on wildlife in Europe and Africa, we predict that species diversity on mires in the study area may continue to decrease despite the fact that most of the mires are nature reserves and have changed little during the last 40 years. We suggest two mechanisms for population change in these pristine breeding areas: 1) most of the mire species are migratory and may be negatively affected by human activities in the wintering areas, or 2) populations on mires are part of larger metapopulations so that population declines in other breeding habitats may affect populations on mires through reduced immigration. We discuss evidence for these two ideas below (sections Migration and winter habitat and Marginal populations).

\section{Forest species}

During censusing of mires, birds in the surrounding forests were also recorded both in 1976-77 and 2015. Censusing forest species while observers stay on mires obviously has some disadvantages, in particular that detectability is biased towards species that vocalize prominently or frequently fly above trees. Thus, species that rarely vocalize or expose themselves (e.g. Capercaillie Tetrao urogallus and Hazel Hen Tetrastes bonasia) will be strongly underrecorded. However, for the species that are easily detected if present (e.g. Common Cuckoos Cuculus canorus and many migratory passerines with high song rates), comparisons of population change within species should not affected by the biases mentioned above because the same method was employed in both census periods. Thus, we argue that our data for many forest species may provide a reasonable estimate of population change.

We found large changes for many of the species recorded. Many of the changes were consistent with results from general surveys of long-term population changes in terrestrial birds (Green \& Lindström 2014, Kålås et al. 2014) and may be linked to general patterns, e.g. related to migratory strategies (see further below). However, for some species we consider that our data represent short-term, cyclic changes (Eurasian Siskin Spinus spinus and crossbills Loxia spp.) because 2015 was a major masting year for spruce in the study area. It should also be noted that our data were limited for some species, so that statistical testing of population changes was not possible, and that we classified species with $\leq$ $50 \%$ population change as stable. Thus, it is possible that a number of other species in reality also had important population changes (e.g. Eurasian Wryneck Jynx torquilla, Wood Lark Lullula arborea, Common Redstart Phoenicurus phoenicurus, see Table 2).

Overall, there were trends that species numbers and abundance of forest birds had increased. However, mire and forest species did not differ in population changes in general. Our data on total abundance of forest birds is biased towards species with high detectability (cf. Methods and above). Despite this, our data corresponded well with quantitative point count data in forests in Oslo and Akershus counties (Haavik \& Dale 2012; partly overlapping geographical extent of study area with present study). The relative abundance of species was strongly correlated between the two studies (analysis using all species $(\mathrm{n}=45)$ recorded by Haavik and Dale (2012; Table 1); mire data from 1976-77: $\mathrm{r}_{\mathrm{S}}=0.53, \mathrm{p}=0.0005$; mire data from 2015: $\left.\mathrm{r}_{\mathrm{s}}=0.65, \mathrm{p}<0.0001\right)$. The main difference was that three low-density species recorded by Haavik and Dale (2012) were not recorded in the present study (Capercaillie, Woodcock Scolopax rusticola, Threetoed Woodpecker Picoides tridactylus). These species constituted only $0.5 \%$ of total abundance in the study by Haavik and Dale (2012). We therefore regard our data as a reasonable estimate of general abundance of forest species around the 18 mires.

\section{Migration and winter habitat}

Similar to previous studies (Sanderson et al. 2006, Laaksonen \& Lehikoinen 2013), we found that resident species had more favourable population changes than long-distance migrants. However, contrary to those 
previous studies, we also found that short-distance migrants were more similar to long-distance migrants than to residents. In our sample of species, shortdistance migrants constituted 10 out of 17 declining species (7 out of 11 among species with significant declines as indicated by the Wilcoxon signed-ranks tests). We suggest that this may be related to the fact that many of the declining short-distance migrants wintered in agricultural areas (e.g. Northern Lapwing, Eurasian Skylark, Meadow Pipit, Yellowhammer). On the other hand, among short-distance migrants with stable or increasing populations, only a few wintered in agricultural areas. Thus, the general problems affecting birds in agricultural areas in Europe (Donald et al. 2001, Laaksonen \& Lehikoinen 2013) also appear to have consequences for birds breeding in other habitats in seemingly pristine environments such as the mire nature reserves in our study, through carry-over effects from the wintering areas.

Among long-distance migrants, we found that some species had declined (Yellow Wagtail, Lesser Whitethroat Sylvia curruca, Red-backed Shrike Lanius collurio) as also indicated by previous studies. However, as mentioned above, we found an increase for the Tree Pipit. Furthermore, contrary to previous studies that have reported a decline of the Common Cuckoo (Kålås et al. 2014, Moksnes 2014), our data did not reveal a long-term decline despite reasonable numbers observed. Mires in southeastern Norway hold an important part of the population of cuckoos, whereas previous data for the cuckoo from Norway have been dominated by the montane part of the population (Kålås et al. 2014). Thus, our data may be more similar to Swedish data, which indicate a small increase in recent years (Green \& Lindström 2014). This is another example suggesting spatial variation in population trend. We suggest that different population trends of cuckoo populations may be linked to different population trends of their hosts. In our study area, the Tree Pipit is probably a major host (S. Dale, personal observations), and this species showed a population increase. On the other hand, in mountain areas some common hosts are declining (e.g. Meadow Pipit; Lehikonen et al. 2014).

\section{Marginal populations}

One striking aspect of the present study was that many species having mires or their surroundings as a marginal breeding habitat (i.e. the major part of the population breeds in another habitat; Arvidsson et al. 1992) have declined. Examples include Northern Lapwing, Blackheaded Gull, Eurasian Skylark, Fieldfare Turdus pilaris, and Yellowhammer. Furthermore, others have these mires as an outpost separated from the main distribution areas (e.g. Meadow Pipit and Yellow
Wagtail which in Norway are predominantly mountain species). Population declines are often first seen at the edge of distribution areas and in marginal areas (Dale 2001, Dale \& Hansen 2013). Thus, declines in marginal populations of such species may act as warning signals that their overall populations are subject to negative impacts. Interestingly, among mire species in our study population change (abundance) was positively correlated with the proportion of the Swedish population that breed on mires (Arvidsson et al. 1992). Thus, specialist mire species have generally increased, whereas species with mires as a marginal habitat have generally declined. Similar to our findings that short-distance migrants wintering in agricultural areas have declined, the main breeding habitat for some marginal and declining species on and around the mires is actually agricultural areas (e.g. Northern Lapwing, Eurasian Skylark and Yellowhammer Emberiza citrinella). This indicates that some species breeding on mires and around may be affected by declines of conspecific populations in other habitats, most likely due to reduced immigration.

\section{Conclusions}

This study has shown that the bird community on mires and in the surrounding forests in the lowlands of southeastern Norway has changed dramatically during the last 40 years. Twenty-two out of 48 species (46\%) with sufficient data for statistical testing showed significant population changes. Although there was an overall decline in species number on mires, there was an equal number of species showing statistically significant declines $(\mathrm{n}=11)$ or increases $(\mathrm{n}=11)$ when combining mire and forest species. Population changes could be linked to migratory strategies and suggest that short-distance migrants wintering in agricultural areas have unfavourable trends. These species are therefore of particular conservation concern. Our results thereby also differ from many previous studies that have highlighted long-distance migrants as having strongest declines. In our study, short-distance migrants appeared to fare just as poorly, and only resident species seem to do well. Our results also indicated that species on mires that had another habitat as main breeding habitat, had more negative population trends than mire specialists. This indicates that problems in agricultural areas may have a two-fold influence on the bird community on mires, both through adverse effects in wintering areas in Europe, and through population declines of species breeding mainly in agricultural areas, which reduces immigration into their marginal populations on mires.

Acknowledgements. We thank Geir A. Sonerud and one anonymous referee for comments on the manuscript. 


\section{REFERENCES}

Andersen, G.S. \& Bergan, M. 2013. Hekkende sjøfugl i indre Oslofjord, Oslo og Akershus 2013. Rapport, Norsk Ornitologisk Forening, avdeling Oslo og Akershus. (In Norwegian)

Arvidsson, B.L., Boström, U., Dahlén, B., de Jong, A., Kolmodin, U. \& Nilsson, S.G. 1992. The importance of mires as breeding habitat for wetland birds in Sweden. Ornis Svecica 2: 67-76.

Breistøl, A. \& Helberg, M. 2012. Dystre tall for hettemåkebestanden i Norge. Vår Fuglefauna 35: 150157. (In Norwegian)

Byrkjedal, I., Kyllingstad, K., Efteland, S. \& Grøsfjell, S. 2012. Population trends of Northern Lapwing, Eurasian Curlew and Eurasian Oystercatcher over 15 years in a southwest Norwegian farmland. Ornis Norvegica 35: 16-22.

Byrkjedal, I. \& Kålås, J.A. 2012. Censuses of breeding birds in a South Norwegian arctic-alpine habitat three decades apart show population declines in the most common species. Ornis Norvegica 35: 43-47.

Cramp, S. \& Perrins, C.M. 1977-94. Birds of the Western Palearctic. Volumes 1-9. Oxford University Press, UK.

Crick, H.Q.P. \& Sparks, T.H. 1999. Climate change related to egg-laying trends. Nature 399: 423-424.

Dale, S. 2001. Female-biased dispersal, low female recruitment, unpaired males, and the extinction of small and isolated bird populations. Oikos 92: 344-356.

Dale, S., Andersen, G.S., Eie, K., Bergan, M. \& Stensland, P. 2001. Guide til fuglelivet i Oslo og Akershus. Norsk Ornitologisk Forening, Oslo og Akershus. (In Norwegian)

Dale, S. \& Hansen, K. 2013. Population decline in the Rustic Bunting Emberiza rustica in Norway. Ornis Fennica 90: 193-202.

de Jong, A. \& Berg, Å. 2001. Storspoven i Sverige. Vår Fågelvärld 60(2): 6-16. (In Swedish)

Donald, P. F., Green, R.E. \& Heath, M.F. 2001. Agricultural intensification and the collapse of Europe's farmland bird populations. Proceedings of the Royal Society B: Biological Sciences 268: 25-29.

Enemar, A., Sjöstrand, B. \& Svensson, S. 1978. The effect of observer variability on bird census results obtained by a territory mapping technique. Ornis Scandinavica 9: 31-39.

Fauchald, P., Anker-Nilssen, T., Barrett, R.T., Bustnes, J.O., Bårdsen, B.J., Christensen-Dalsgaard, S., Descamps, S., Engen, S., Erikstad, K.E., Hanssen, S.A., Lorentsen, S.-H., Moe, B., Reiertsen, T.K., Strøm, H. \& Systad G.H. 2015. The status and trends of seabirds breeding in Norway and Svalbard. NINA Report 1151.

Fredriksen, Å.S., Haga, A., Hardeng, G., Johansen, P.-A., Lågbu, Ø., Sørlie, T. \& Viker, V. 2011. Artsliste, bestander og trender. Østfold-Natur 46: 157-165. (In Norwegian)

Fremstad, E. 1997. Vegetasjonstyper i Norge. NINA
Temahefte 12: 1-279. (In Norwegian with English summary)

Fuller, R.J., Gregory, R.D., Gibbons, D.W., Marchant, J.H., Wilson, J.D., Baillie, S.R. \& Carter, N. 1995. Population declines and range contractions among lowland farmland birds in Britain. Conservation Biology 9: 1425-1441.

Green, M. \& Lindström, Å. 2014. Övervakning av fåglarnas populationsutveckling. Årsrapport för 2013. Biologiska institutionen, Lunds universitet. (In Swedish)

Haavik, A. \& Dale, S. 2012. Are reserves enough? Value of protected areas for boreal forest birds in southeastern Norway. Annales Zoologici Fennici 49: 69-80.

Hardeng, G. 2014. Fuglefaunaen på myrene Midtfjellmosen og Store Rekke i Aurskog-Høland, Akershus, i 1975-77 og i 2014. Fauna 67: 118-131. (In Norwegian with English summary)

Heggøy, O. \& Øien, I.J. 2014. Vipa går en usikker framtid i møte. Vår Fuglefauna 37: 114-127. (In Norwegian)

Husby, M. \& Stueflotten, S. 2009. Norsk Hekkefugltaksering - Bestandsutvikling i HFT-områdene for 57 arter 19952008. Norsk Ornitologisk Forening, rapport 6-2009. (In Norwegian)

Inger, R., Gregory, R., Duffy, J.P., Stott, I., Voříšek P. \& Gaston, K.J. 2015. Common European birds are declining rapidly while less abundant species' numbers are rising. Ecology Letters 18: 28-36.

Kålås, J.A., Husby, M., Nilsen, E.B. \& Vang, R. 2014. Bestandsvariasjoner for terrestriske fugler i Norge 1996-2013. Norsk Ornitologisk Forening, rapport 4-2014. (In Norwegian)

Laaksonen, T. \& Lehikoinen, A. 2013. Population trends in boreal birds: continuing declines in agricultural, northern, and long-distance migrant species. Biological Conservation 168: 99-107.

Lehikoinen, A., Green, M., Husby, M., Kålås, J.A. \& Lindström, A. 2014. Common montane birds are declining in northern Europe. Journal of Avian Biology 45: 3-14.

Moksnes, A. 2014. Hvor blir det av gjøken? Vår Fuglefauna 37: 22-23. (In Norwegian)

Nilsson, S. 2014. Long-term trends in the number of Whooper Swans Cygnus cygnus breeding and wintering in Sweden. Wildfowl 64: 197-206.

Prange, H. 2005. The status of the Common Crane (Grus grus) in Europe - breeding, resting, migration, wintering and protection. North American Crane Workshop Proceedings, paper 38.

Sanderson, F.J., Donald, P.F., Pain, D.J., Burfield, I.J. \& van Bommel, F.P.J. 2006. Long-term population declines in Afro-Palearctic migrant birds. Biological Conservation 131: 93-105.

Shimmings, P. \& Øien, I.J. 2015. Bestandsestimater for norske hekkefugler. Norsk Ornitologisk Forening, rapport 2-2015. (In Norwegian with English summary)

Vickery, J.A., Ewing, S.R., Smith, K.W., Pain, D.J., Bairlein, F., Skorpilova, J. \& Gregory, R.D. 2014. The decline 
of Afro-Palaearctic migrants and an assessment of potential causes. Ibis 156: 1-22.

Walther, G.-R., Post, E., Convey, P., Menzel, A., Parmesan, C., Beebee, T.J.C., Fromentin, J.-M., Hoegh-Guldberg, O. \& Bairlein, F. 2002. Ecological responses to recent climate change. Nature 416: 389-395.
Wilson, J.D., Taylor, R. \& Muirhead, L.B. 1996. Field use by farmland birds in winter: an analysis of field type preferences using resampling methods. Bird Study 43: $320-332$.

Received 3 February 2016. Accepted 27 April 2016

Appendix 1. Location, characteristics and number of species and individuals recorded for 18 mires included in the study. Sites in bold are nature reserves. Site ID is the same as used in Figure 1 in main text.

\begin{tabular}{|c|c|c|c|c|c|c|c|c|c|}
\hline \multirow[b]{2}{*}{ ID } & \multirow[b]{2}{*}{ Site } & \multirow[b]{2}{*}{ Municipality } & \multirow[b]{2}{*}{ County ${ }^{1}$} & \multirow[b]{2}{*}{$\begin{array}{c}\text { Eleva- } \\
\text { tion } \\
(\mathrm{m})\end{array}$} & \multirow[b]{2}{*}{$\begin{array}{c}\text { Area } \\
\text { (ha) }\end{array}$} & \multicolumn{2}{|c|}{ No. of species } & \multicolumn{2}{|c|}{ No. of individuals } \\
\hline & & & & & & $\begin{array}{l}1976 \\
-77\end{array}$ & 2015 & $\begin{array}{c}1976 \\
-77\end{array}$ & 2015 \\
\hline 1 & Tranemosen & Halden & $\varnothing \mathrm{F}$ & 170 & 36.2 & 4 & 3 & 15 & 16 \\
\hline 2 & Langmyr & Halden & $\varnothing \mathrm{F}$ & 185 & 23.7 & 6 & 4 & 19 & 12 \\
\hline 3 & Ilemyr & Hvaler & $\varnothing \mathrm{F}$ & 45 & 4.3 & 4 & 1 & 7 & 2 \\
\hline 4 & Jørstadmyra (Langmyr) & Sarpsborg & $\varnothing F$ & 65 & 14.5 & 4 & 4 & 11 & 15 \\
\hline 5 & Stordamsmyra & Fredrikstad & $\varnothing \mathrm{F}$ & 65 & 10.4 & 4 & 3 & 18 & 11 \\
\hline 6 & Bøensmosen & Rakkestad & $\varnothing \mathrm{F}$ & 180 & 38.7 & 6 & 5 & 24 & 33 \\
\hline 7 & Spernesmosen & Marker & $\varnothing \mathrm{F}$ & 145 & 13.2 & 7 & 2 & 16 & 6 \\
\hline 8 & Langrasta-Fossemyra & Marker & $\varnothing F$ & 140 & 9.1 & 1 & 1 & 6 & 4 \\
\hline 9 & Kallakmosen & Trøgstad & $\varnothing F$ & 135 & 60.9 & 10 & 8 & 41 & 39 \\
\hline 10 & Igletjernmosan & Våler & $\varnothing \mathrm{F}$ & 160 & 19.5 & 5 & 6 & 17 & 19 \\
\hline 11 & Ishavet & Vestby & $\mathrm{AK}$ & 55 & 10.3 & 3 & 2 & 7 & 6 \\
\hline 12 & Tomåsan & Nesodden & $\mathrm{AK}$ & 185 & 11.6 & 3 & 2 & 9 & 8 \\
\hline 13 & Breidmåsan & Fet & $\mathrm{AK}$ & 210 & 63.0 & 10 & 9 & 38 & 49 \\
\hline 14 & Store Rekket & Aurskog-Høland & $\mathrm{AK}$ & 285 & 61.8 & 15 & 10 & 48 & 54 \\
\hline 15 & Midtfjellmåsan & Aurskog-Høland & $\mathrm{AK}$ & 280 & 63.5 & 18 & 19 & 78 & 94 \\
\hline 16 & Sakosmåsan & Nes & $\mathrm{AK}$ & 330 & 17.4 & 7 & 4 & 17 & 14 \\
\hline 17 & Havmyra & Sør-Odal & $\mathrm{HE}$ & 420 & 37.4 & 10 & 11 & 39 & 49 \\
\hline 18 & Linåsmyra & Eidskog & $\mathrm{HE}$ & 125 & 38.8 & 12 & 11 & 27 & 35 \\
\hline
\end{tabular}

${ }^{1} \varnothing \mathrm{F}=$ Østfold, $\mathrm{AK}=$ Akershus, $\mathrm{HE}=$ Hedmark 
Appendix 2. Classification of migratory status and winter habitat ${ }^{1}$ of species recorded in the study. Species recorded in $<3$ sites 1976-77 and 2015 combined) were excluded because these species were not included in analyses of migratory status or winter habitat. See Table 1 and 2 in main text for scientific names of species.

Mire species

Resident

Short-distance migrant

Long-distance migrant

Resident

Short-distance migrants

Long-distance migrant

\section{Black Grouse}

Common Teal, Mallard, Common Goldeneye, Red-throated Diver, Common Crane, European Golden Plover, Northern Lapwing, Eurasian Curlew, Black-headed Gull, Common Gull, Eurasian Skylark, Meadow Pipit, White Wagtail

Common Sandpiper, Green Sandpiper, Wood Sandpiper, Tree Pipit, Yellow Wagtail, Whinchat

\section{Forest species}

Black Woodpecker, Great Spotted Woodpecker, Goldcrest, Blue Tit, Great Tit, Coal Tit, Crested Tit, Willow Tit, Eurasian Treecreeper, Eurasian Jay, Hooded Crow, Eurasian Siskin, Common Redpoll, crossbills, Eurasian Bullfinch

Common Woodpigeon, Wood Lark, Eurasian Wren, Dunnock, European Robin, Common Blackbird, Fieldfare, Song Thrush, Redwing, Mistle Thrush, Common Chaffinch, Brambling, Yellowhammer

Common Cuckoo, Barn Swallow, Common Redstart, Lesser Whitethroat, Garden Warbler, Willow Warbler, Spotted Flycatcher, Pied Flycatcher, Red-backed Shrike

\footnotetext{
${ }^{1}$ Winter habitat was classified for short-distance migrants: wetlands (plain text), agricultural areas (bold) and forest (including other terrestrial habitats with cover; italics).
}

Appendix 3. Assessing significance of population changes - comparison of performance of three tests.

This study had data on population sizes at two time periods for all 18 study sites, and changes in population sizes could then be assessed with a pairwise design. Standard statistical tests for pairwise changes in observed numbers are paired t-tests (parametric) and Wilcoxon signed-ranks tests (non-parametric). A third alternative is the program TRIM (Pannekoek, J. \& van Strien, A. 2005. TRIM 3 Manual (TRends \& Indices for Monitoring data). Statistics Netherlands, Voorburg, Netherlands) which is widely used for estimating population trends and employs Poisson regression of time series of counts. However, TRIM is not well suited for estimating population changes between two time periods. Although TRIM in general gave similar results as paired t-tests and Wilcoxon signed-ranks tests, TRIM failed to give results for species that became extinct in all sites.

As a parametric test, paired t-tests require normally distributed data, and counts in our data were often strongly skewed. Thus, the paired t-test performed poorly in some cases, in particular the same cases where TRIM failed to give results (extinction in all sites). Otherwise, paired t-tests and Wilcoxon signed-ranks tests generally gave similar results. The Wilcoxon signed-ranks tests performed well with all types of data and returned consistently biologically meaningful results. One potential drawback of the Wilcoxon signed-ranks test is that all cases of no change are excluded (TRIM and paired t-tests do not exclude such cases). Thus, if a substantial proportion of sites have identical counts in each time period, one may misleadingly obtain a test result showing a significant change based on a minority of sites showing a change in one direction. In general, there were rather few cases of no change in our data sets, and there were no cases where this may have resulted in a clearly misleading p-value (except perhaps for the Common Woodpigeon). In conclusion, we chose to use Wilcoxon signed-ranks tests because they consistently returned robust and biologically meaningful results, including those cases in which TRIM had problems due to complete extinction and paired t-tests were inappropriate because of non-normally distributed data. 
Appendix 4. Long-term trends versus year-to-year variation

Our estimates of population changes were based on censuses done at two time periods 40 years apart. To assess to what degree they were likely to represent long-term trends, and not just year-to-year variation in population size, we made comparisons with population changes in consecutive years in our study sites [within 1975-77 (G. Hardeng, unpublished data) and between 2014 (Hardeng 2014) and 2015 (this study)]. In addition, we used two previous studies to assess what represents normal magnitude of long-term changes versus year-to-year variation.

\section{Population changes in consecutive years in own study sites versus long-term changes}

Some of the sites included in our study have been censused in consecutive years (this study, Hardeng 2014, G. Hardeng, unpublished data). We extracted the most comparable censuses from consecutive years, following the rationale described in main methods if there were several censuses available from one year. There were data for eight comparisons of year-to-year changes (Store Rekket: 1975-76, 1976-77, 2014-15; Midtfjellmåsan: 1975-76, 1976-77, 2014-15; Breidmåsan: 1975-76; Sakosmåsan: 1976-77). Birds in surrounding forest areas were not recorded quantitatively in 1975 and 2014, thus limiting sample size, so comparisons were only based on mire species.

Year-to-year changes of mire species for which long-term changes had been tested statistically (see Table $1 ; \mathrm{n}=15$ species), had a median absolute value of 33\%, whereas their long-term changes had a median absolute value of $77 \%$ (cf. Table 1). In pairwise comparisons of species, long-term changes were larger than year-to-year changes (Wilcoxon signed-ranks test: $\mathrm{z}=1.99, \mathrm{n}=15, \mathrm{p}=0.047)$.

\section{Year-to-year variation versus long-term changes in previous studies}

Thingstad (Ornis Norvegica (2015), 38: 18-24) compared number of territories of wetland birds in two marshes in Central Norway in 1971 and 1972, and again in 2011 and 2012. Among species $(n=8)$ that had at least four territories in at least one year, changes between two consecutive years had a median absolute value of $28 \%$, whereas long-term changes between 1971 or 1972 and 2011 or 2012 had a median absolute value of $57 \%$. Although six out of eight species showed larger changes in the long-term than between years, this difference was not significant in pairwise comparisons (Wilcoxon signed-ranks test: $\mathrm{z}=0.84, \mathrm{n}=8, \mathrm{p}=0.40$ ).

Byrkjedal and Kålås (Ornis Norvegica (2012), 35: 43-47) compared number of territories of mountain birds in one area of Hardangervidda, southern Norway, in 1980 and again in 2010 and 2011. Changes between 2010 and 2011 (estimated from their Figure 2) had a median absolute value of 19\% ( $\mathrm{n}=8$ species), whereas long-term changes between 1980 and the mean of 2010 and 2011 had a median absolute value of 57\%. In pairwise comparisons of species, long-term changes were larger than year-to-year changes (Wilcoxon signed-ranks test: $\mathrm{z}=2.10, \mathrm{n}=8, \mathrm{p}=0.036$ ).

These results match our results well; year-to-year changes of mire species had a median absolute value of $33 \%$ (see above). Long-term changes of mire species had a median absolute value of $77 \%$ (see above), forest species had a median absolute value of $89 \%(n=33)$, and both mire and forest species $(n=48)$ combined had a median absolute value of $86 \%$ (cf. Table 1 and 2 ).

\section{Conclusions}

Data from our own study sites indicated year-to-year changes were significantly smaller than the changes we observed between 1976-77 and 2015. Two other published studies also indicated that year-to-year variation were much smaller than the changes we observed between 1976-77 and 2015. Overall, our long-term changes had a median absolute value of $77-89 \%$ compared to the median absolute values of $19-33 \%$ reported above for year-to-year variation. Note that we used a change of $>50 \%$ as the limit for classifying species as declining or increasing. Species with $\leq 50 \%$ change were classified as stable, and $\leq 50 \%$ change matches the normal magnitude of year-to-year variation. Note also that all species that had significant changes between 1976-77 and 2015 also had $>50 \%$ change. Overall, our conclusion is that the significant changes we observed between 1976-77 and 2015 represent long-term trends and not just year-to-year variation because they were larger than normal year-to-year variation. 